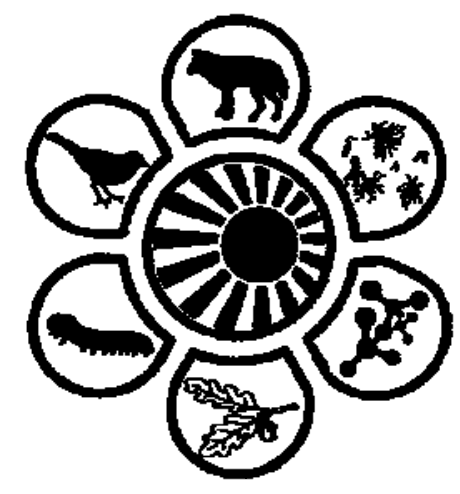

Вісник Дніпропетровського університету. Біологія, екологія.

Vìsnik Dnìpropetrovs'kogo unìversitetu. Seriâ Bìologiâ, ekologiâ

Visnyk of Dnipropetrovsk University. Biology, ecology.

Vìsn. Dnìpropetr. Unìv. Ser. Bìol. Ekol. 2015. 23(2), 100-104.

doi: $10.15421 / 011514$

ISSN 2310-0842 print

ISSN 2312-301X online

www.ecology.dp.ua

UDC 581.13:577.15/581.45

\title{
Physiological and biochemical reactions of Hordeum vulgare seedlings to the action of silver nanoparticles
}

\author{
N.O. Khromykh, L.V. Shupranova, Y.V. Lykholat, V.S. Bil'chuk, \\ V.S. Fedenko, L.V. Boguslavs'ka, O.I. Borysova \\ Oles Honchar Dnipropetrovsk National University, Dnipropetrovsk, Ukraine
}

\begin{abstract}
Morphometrical indexes, and spectrophotometrically measured protein and glutathione (GSH, GSSG) contents and activity of peroxidase (POD, EC 1.11.1.7), glutathione-reductase (GR, EC 1.6.4.2) and glutathione S-transferase (GST, EC 2.5.1.18) were examined in Hordeum vulgare L. seedlings after 0.01 and $0.1 \mathrm{mg} / 1$ AgNPs treatment during $24 \mathrm{~h}$. We tested the hypothesis that the action of nanoparticles has a stressful effect on the physiological and biochemical processes of seedlings. Growth of roots was inhibited and fresh weight decreased by $29 \%$ and $21 \%$ under low and high concentrations respectively. Conversely, leaf growth was intensified, and leaf length (16\% and $18 \%)$ and fresh weight (35\% and 44\%) increased at low and high concentrations respectively. POD activity in roots increased by $26 \%$ and $7 \%$, and decreased in leaves to $57 \%$ and $81 \%$ of control at low and high concentrations respectively. GSH content changed insignificantly, but GSSG content increased in roots ( 2 and 2.5 -fold) and in leaves (13\% and 30\%) at both AgNPs concentrations. GSH/GSSG-ratio decreased in roots (1.9 and 2.6-fold) and in leaves (1.1 and 1.3-fold) at low and high concentrations respectively. GR activity decreased at a concentration of $0.01 \mathrm{mg} / 1$ ( $7 \%$ in roots and $17 \%$ in leaves respectively) and increased at $0.1 \mathrm{mg} / 1$ ( $52 \%$ in roots and $6 \%$ in leaves). GST activity increased in leaves (52\% and $78 \%$ at low and high concentrations) but decreased by $17 \%$ in roots under high concentration of nanosilver. Thus, the action of AgNPs on barley seedlings had a dose-dependent and organ-specific character. The various directions of changes in growth, metabolic processes and activity of antioxidant defense systems appear to be a stress response of barley seedlings to the impact of AgNPs, which underlines the necessity of detailed study of plant intracellular processes exposed to the action of nanomaterial.
\end{abstract}

Keywords: barley; peroxidase; glutathione; glutathione reductase; glutathione-S-transferase; nanosilver

\section{Фізіолого-біохімічні реакції проростків Hordeum vulgare на дію наночасток срібла}

\author{
Н.О. Хромих, Л.В. Шупранова, Ю.В. Лихолат, В.С. Більчук, \\ В.С. Феденко, Л.В. Богуславська, О.І. Борисова
}

Дніпропетровський начіональний університет ім. Олеся Гончара Дніпропетровськ

Досліджено вплив наночасток срібла (AgNPs) у концентраціях 0,01 і 0,1 мг/л на морфометричні показники, вміст білка, глутатіону (GSH i GSSG) та активність антиоксидантних ферментів у проростках ячменю (Hordeum vulgare L.). За обох концентрацій AgNPs виявлено пригнічення росту коренів при зростанні площі та сирої маси листків. Активність пероксидази (POD, EC 1.11.1.7) у коренях зростала за обох концентрацій, тоді як у листках знижувалась. За незмінного вмісту GSH в обох органах проростків виявлено накопичення GSSG. Активність глутатіон-редуктази (GR, EC 1.6.4.2) інгібувалась за низької концентрації наносрібла та зростала за високої. Активність глутатіон-S-трансферази (GST, EC 2.5.1.18) зростала тільки у листках проростків за обох концернтрацій AgNPs. Виявлені дозово-залежні та органоспецифічні ефекти свідчать про стресовий характер дії наночасток срібла на метаболічні процеси у проростках ячменю та обумовлюють необхідність детальних досліджень дії наноматеріалів на рослини.

Ключові слова: ячмінь; пероксидаза; глутатіон; глутатіон-редуктаза; глутатіон-S-трансфераза; наносрібло

Дніпропетровський наиіональний університет імені Олеся Гончара, пр. Гагаріна, 72, Дніпропетровськ, 49010, Украӥна Oles Honchar Dnipropetrovsk National University, Gagarin Ave., 72, Dnipropetrovsk, 49010, Ukraine

Tel.: +38-056-760-84-38.E-mail:khromykh58@rambler.ru 


\section{Introduction}

Modern nanotechnologies are used intensively in agronomy in order to provide rational selection of disease control molecules, as Rezvany et al. (2012) reported, or control slow-release pesticides and develop diagnostic tools, according to Ashrafi et al. (2013). Silver nanoparticles (AgNPs) are among those most commonly used; and it has been shown (Choi et al., 2009; Nair et al., 2010; Lee et al., 2012), that they have antibacterial, antifungal and antiviral effects and also reduce damage from diseases.

Analysis of research reports reveals variations in the effect of the action of silver nanoparticles on the growth, development and metabolic processes of different plant species. In this context Lee et al. (2012) emphasized that the phytotoxic effect of nano-silver on Phaseolus radiatus and Sorghum bicolor seedlings caused concentration-dependent delay of growth. On the other hand, Syu et al. (2014) reported that spherical AgNPs had no influence on the growth of Arabidopsis seedling roots. An et al. (2008) focused on the preliminary treatment by nano-silver which resulted in the extension of the storage period of asparagus shoots. Seif et al. (2011) discovered that using silver nanoparticles instead of $\mathrm{AgNO}_{3}$ provided improvement of Borago officinalis L. seed yield. Similar results were obtained by Ashrafi et al (2013) in an experiment on soybeans (Glycine max L.) where increase in mass of 100 seeds, crop quantity and crop capacity was observed after treatment by nano-silver.

As Khot et al. (2012) noted, the main purpose of most researchers lay in the considerable agronomic advantage of nanotechnologies, whereas influence on plants' metabolism has received little attention. However, Krishnaraj et al. (2012) observed an increase in catalase and peroxidase activity in Bacopa monnieri seedlings treated by silver nanoparticles, and interpreted this effect as a response to stress caused by penetration of AgNPs into plant tissues. Syu et al. (2014) discovered anthocyanin accumulation as well as $\mathrm{Cu} / \mathrm{Zn}$-superoxide dismutase activation and ROS accumulation as a result of the action of nano-silver on Arabidopsis seedlings. Thus, the results introduced illustrate a variety of plant reactions and suggest that there is insufficient information on the action of nanoparticles on intracellular processes of plants. In the present study, the physiological and biochemical responses of barley seedlings were investigated after the seeds were exposed to different concentrations of AgNPs in order to test the hypothesis of the stressful character of the action of nanoparticles.

\section{Materials and methods}

The test objects were roots and leaves of 7-days seedlings of Hordeum vulgare (cultivar Dniprovskiy 257, obtained from the State Selection Center, Sinelnykovo, Ukraine). The seeds were sterilized in 5\% sodium hypochlorite solution for $10 \mathrm{~min}$ and rinsed with deionized water several times. After that, the seeds were placed in Petri dishes (30 seeds per dish) with solutions of AgNPs (produced by "Nanomaterial and Nanotechnologies", Kyiv, Ukraine) in concentration of 0.01 and $0.1 \mathrm{mg} / 1$, control seeds were placed in water; the temperature was $25^{\circ} \mathrm{C}$ for both the experimental and the control seeds. After $24 \mathrm{~h}$ the seeds were rinsed with water, wrapped in humid filter paper, and seedlings were grown further in water under controlled conditions of temperature $\left(22^{\circ} \mathrm{C}\right)$ and illumination (dark/light cycle - 16/8 h).

The protein content in barley roots and leaves was measured according to Bradford (1976) method and expressed in mcg per $\mathrm{g}$ tissue fresh weight $(\mathrm{mcg} / \mathrm{g} \mathrm{FW})$.

Determination of the reduced glutathione (GSH) was based on spectrophotometric registration of the glutathione reaction with Ellman's reagent (dithiobis-2-nitrobenzoic acid), described by Anderson (1985). No-protein samples were obtained by centrifugation $(10,000 \mathrm{~g}$ for $15 \mathrm{~min})$ of crude extracts $(250 \mathrm{mg}$ fresh tissue homogenized with $1.5 \mathrm{ml}$ of 5\% 5-sulfosalicylic acid). Optical density of reactive mixture $(1.1 \mathrm{ml}$ of $0.1 \mathrm{M} \mathrm{K}$-phosphate buffer contained EDTA, and $0.3 \mathrm{ml}$ of sample) was registered at $412 \mathrm{~nm}$ a $10 \mathrm{~min}$ later on adding $0.15 \mathrm{ml}$ of Ellman's reagent. GSH content was calculated by using calibration graph and expressed in $\mathrm{mcg} / \mathrm{g} \mathrm{FW}$. Total glutathione content was measured through the same procedure after reducing oxidized glutathione by adding zinc dust to the no-protein samples, according to Woodward and Fry (1932). Disulfide (GSSG) content was calculated as the difference between total and reduced glutathione amounts (GSSG molecular mass was taken into account) and expressed in $\mathrm{mcg} / \mathrm{g} \mathrm{FW}$.

Supernatants for determination of glutathione-dependent enzymes activity were obtained by centrifugation $(12,000 \mathrm{~g}$ for $20 \mathrm{~min}$ and $4{ }^{\circ} \mathrm{C}$ ) of plants' crude extracts $(200 \mathrm{mg}$ of fresh tissue homogenized with $1.0 \mathrm{ml}$ of phosphate buffer contained $1 \mathrm{mM}$ EDTA, $\mathrm{pH}$ 7.0). Reactive mixtures were incubated at $30{ }^{\circ} \mathrm{C}$, and optical density change was detected at $340 \mathrm{~nm}$. The assay of glutathione S-transferase (GST, EC 2.5.1.18) activity was based on the method proposed by Habig et al. (1974) with 1-chloro-2,4-dinitrobenzene (CDNB) as a substrate; enzyme activity was expressed in nanoM CDNB/sec g FW (nkat/g FW). Glutathione reductase activity (GR, EC 1.6.4.2) was measured according to Carlberg and Mannervik (1985) in a reactive mixture containing $0.1 \mathrm{M}$ phosphate buffer contained $1 \mathrm{mM}$ EDTA $(\mathrm{pH} 7.4)$, $2 \mathrm{mM}$ GSSG, $1 \mathrm{mM}$ NADPH, and $0.1 \mathrm{ml}$ sample; the result was expressed in nanoM NADPH/sec g FW (nkat/g FW). Determination of peroxidase (POD, EC 1.11.1.7) activity was based on the method of Ros Barcelo (1987) with benzidine as a protons donor. Plant roots and leaves (100 mg fresh tissue) were homogenized with $1.5 \mathrm{ml}$ of acetate buffer, $\mathrm{pH}$ 5.4. Supernatants were obtained by centrifugation $\left(12,000 \mathrm{~g}\right.$ for $20 \mathrm{~min}$ and at $\left.4{ }^{\circ} \mathrm{C}\right)$ of crude plants extracts. Optical density change was registered for $1 \mathrm{~min}$ at $470 \mathrm{~nm}$ after adding $1 \% \mathrm{H}_{2} \mathrm{O}_{2}$ to reactive mixture $(0.8 \mathrm{ml}$ of acetate buffer, $1 \mathrm{ml}$ of $0.02 \mathrm{mM}$ benzidine and $0.2 \mathrm{ml}$ sample), and the result was expressed in optical units/min $\mathrm{g} \mathrm{FW}$.

All determinations were performed in three replicates. Data represent mean values and standard deviations $( \pm$ SD). Significance of differences was estimated using Student's ttest $(\mathrm{P}<0.05)$, and asterisk $(*)$ indicates significant difference with control.

\section{Results and discussion}

The changes of growth parameters of barley seedlings roots and leaves varied under the action of silver nanoparticles in different concentrations, as shown in Table 1. 
The fresh weight of barley roots decreased significantly $(29 \%$ and $23 \% ; \mathrm{P}<0.05)$ both at low and high concentration of nano-silver. The results obtained coordinate with the data obtained by Salama (2012) on inhibition of growth of common bean (Phaseolus vulgaris) and corn (Zea mays) roots by silver nanoparticles at certain concentrations. The inhibition can be attributed to the properties of silver ions, because, as was shown by Rezvani et al. (2012), they play an important role in regulating morphogenesis, including root induction. Retardation of roots growth was also revealed by Lin and Xing (2008) in ryegrass seedlings exposed to the action of
nano-Zn particles. On the whole, Salama (2008) stated that inhibition of root growth varies among different plant species and nanoparticles.

By contrast, barley leaf growth intensified at low and high concentrations of nano-silver; the length of seedlings increased by $16 \%$ and $18 \%$, leaf surface area by $13 \%$ and $20 \%$, and leaf fresh weight by $35 \%$ and $44 \%$ respectively ( $\mathrm{P}<0.05$ for all results). Similar increase in length and fresh weight of corn and common bean leaves was observed by Salama (2008) at AgNPs concentration above 60 ppm.

Effect of AgNPs on growth and protein content of Hordeum vulgare seedlings (Mean \pm SD)

\begin{tabular}{|l|r|r|r|}
\hline \multicolumn{1}{|c|}{ Parameters, units } & \multirow{2}{*}{ Control, $\mathrm{H}_{2} \mathrm{O}$} & \multicolumn{2}{c|}{ Nano-silver concentration } \\
\cline { 3 - 4 } & & $0.01 \mathrm{mg} / \mathrm{l}$ & \multicolumn{1}{c|}{$0.1 \mathrm{mg} / \mathrm{l}$} \\
\hline Root fresh weight, $\mathrm{mg}(\mathrm{n}=60)$ & $69.8 \pm 1.12$ & $49.9 \pm 0.98^{*}$ & $53.4 \pm 0.79^{*}$ \\
\hline Leaf length, mm $(\mathrm{n}=60)$ & $120.1 \pm 4.30$ & $139.8 \pm 6.71^{*}$ & $141.8 \pm 6.52^{*}$ \\
\hline Leaf surface area, $\mathrm{cm}^{2}(\mathrm{n}=60)$ & $3.0 \pm 0.16$ & $3.5 \pm 0.25^{*}$ & $3.6 \pm 0.25^{*}$ \\
\hline Leaf fresh weight, $\mathrm{mg}(\mathrm{n}=60)$ & $62.4 \pm 1.31$ & $84.0 \pm 1.55^{*}$ & $89.5 \pm 1.52^{*}$ \\
\hline Leaf fresh weight/surface area, $\mathrm{mg} / \mathrm{cm}^{2}(\mathrm{n}=60)$ & $21.1 \pm 0.46$ & $23.8 \pm 0.43^{*}$ & $25.2 \pm 0.58^{*}$ \\
\hline Seedling fresh weight/seed weight, $\mathrm{mg} / \mathrm{mg}(\mathrm{n}=60)$ & $1.8 \pm 0.03$ & $1.9 \pm 0.05^{*}$ & $2.1 \pm 0.05^{*}$ \\
\hline Leaf protein content, $\mathrm{mg} / \mathrm{g}(\mathrm{n}=9)$ & $3.3 \pm 0.32$ & $4.6 \pm 0.21^{*}$ & $4.9 \pm 0.19^{*}$ \\
\hline Root protein content, $\mathrm{mg} / \mathrm{g}(\mathrm{n}=9)$ & $11.5 \pm 0.18$ & $13.6 \pm 0.33^{*}$ & $13.7 \pm 0.22^{*}$ \\
\hline
\end{tabular}

The leaf fresh weight/surface area ratio in barley seedlings exceeded the control level (13\% and 19\%) at low and high concentrations of nano-silver. This seems to be similar to the effect of iron ions on sunflower seedlings, observed by Ranieri et al. (2001) and attributed to the possible influence of ions on the lignification process in leaves.

In our study, the ratio of barley seedling (roots, shoots, leaves) weight to seed weight exceeds control both at low and high concentration of silver nanoparticles, which could indicate acceleration of metabolite flow from seed to seedling organs under the action of AgNPs.

Nano-silver action both at low and high concentrations induced enhancement of protein accumulation in barley roots (42\% and 49\%; $\mathrm{P}<0.05)$ and leaves $(18 \%$ and $20 \%$; $\mathrm{P}<$ $0.05)$. The results obtained coordinate with the data obtained by Salama (2008) on the significant (30\% for common bean and $24 \%$ for corn) increase in the amount of protein at low concentration of AgNPs.

The results showed that the effects of nano-silver on POD activity differed for the roots and leaves of barley seedlings as shown in Figure 1. Enzyme activity increased in roots at low (30\% above control; $\mathrm{P}<0.05)$ and high concentration ( $9 \%$ above control), whereas it declined significantly in leaves ( $43 \%$ and $19 \%$ below control; $\mathrm{P}<0.05)$.

Ranieri et al. (2001) emphasized that changes in plant peroxidase activity indicated oxidative stress, therefore the effect of AgNPs on barley seedlings must be considered as a stress factor. The decrease in peroxidase activity suggests that nano-silver has a toxic effect on barley leaves; whereas the increase in activity may be attributed to stress-induced enzyme expression in barley roots.

In our study, the GSH content both in barley roots and leaves changed insignificantly, whereas the GSSG content increased greatly both at low and high concentration of silver nanoparticles (Table 2). There was a considerable increase in the amount of oxidized glutathione in barley roots (2.0 and 2.2-fold at low and high concentrations of nano-silver re- spectively), and less in leaves of barley seedlings ( $6 \%$ and $24 \%$ above control level).

According to Noctor et al. (2002), the increase in the level of GSSG together with support of the GSH pool in plant cells must be effected through induction of glutathione biosynthesis and/or reduction; therefore the action of AgNPs could cause activation of the glutathione system in barley roots and leaves. Such supposition is in accordance with the data obtained by Elechiguerra et al. (2005) on damage to bacterial cells by interaction of silver nanoparticles with sulfur-containing proteins in the bacterial membrane and by Noctor et al. (1998) on the ability of glutathione to reduce proteins SH-links. This would lead one to expect an intensive protective role of glutathione under the action of AgNPs in plants as well. However, this aspect has remained insufficiently studied up to the present.

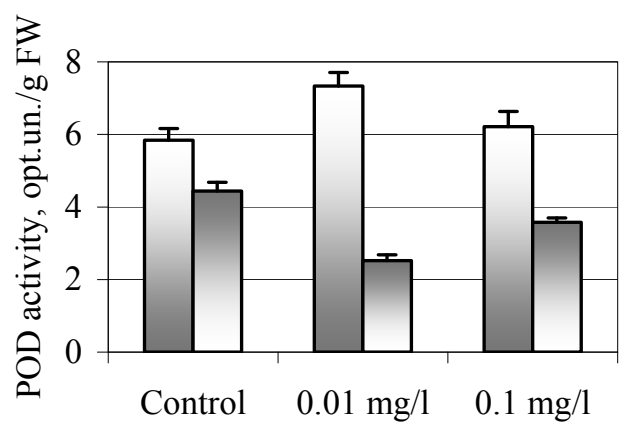

Nanosilver concentration

$\square$ roots $\square$ leaves

\section{Fig. 1. Effect of AgNPs on POD activity of Hordeum vulgare seedlings}

According to our results, the GSH/GSSG ratio diminished in both organs of barley seedlings; in roots however, this was shown more significantly (2.0 and 2.2-fold at low 
and high concentrations of nano-silver). This effect may appear to be an additional cause of barley root growth inhibition, since Gill and Tuteja (2010) showed that a glutathione redox state contributes to cell homeostasis and plant development as a whole.

In our study, the effect of silver nanoparticles on GR activity both in barley roots and leaves was determined by the dose of AgNPs (Fig. 2). Low concentration decreased enzyme activity in roots and leaves (7 and 14\% respectively), whereas high concentration caused significant increase GR activity $(65 \%$ and $10 \%$ in roots and leaves; $\mathrm{P}<0.05)$. This seems to be similar to the induction of GR expression in barley seedlings under the action of nano-silver at a concentration of $0.1 \mathrm{mg} / \mathrm{l}$.

Effect of AgNPs on glutathione content (mcg/g FW) of Hordeum vulgare seedlings (Mean \pm SD)

Table 2

\begin{tabular}{|c|c|c|c|c|}
\hline Organs of seedlings & $\begin{array}{c}\text { Nano-silver } \\
\text { concentration, mg/l }\end{array}$ & $\begin{array}{c}\text { GSH content, } \\
\mathrm{mcg} / \mathrm{g} \mathrm{FW}(\mathrm{n}=6)\end{array}$ & $\begin{array}{c}\text { GSSG content, } \\
\mathrm{mcg} / \mathrm{g} \mathrm{FW}(\mathrm{n}=6)\end{array}$ & GSH/GSSG ratio \\
\hline \multirow{3}{*}{ Roots } & 0.01 & $235.2 \pm 2.66^{*}$ & $10.5 \pm 1.53^{*}$ & 22.4 \\
\hline & 0.1 & $226.9 \pm 2.60$ & $11.5 \pm 1.45^{*}$ & 19.7 \\
\hline & Control, $\mathrm{H}_{2} \mathrm{O}$ & $227.9 \pm 2.37$ & $5.2 \pm 0.95$ & 43.7 \\
\hline \multirow{3}{*}{ Leaves } & 0.01 & $226.1 \pm 6.95$ & $15.9 \pm 1.36^{*}$ & 14.2 \\
\hline & 0.1 & $229.8 \pm 4.92$ & $17.8 \pm 1.73^{*}$ & 12.9 \\
\hline & Control, $\mathrm{H}_{2} \mathrm{O}$ & $227.3 \pm 4.14$ & $14.4 \pm 1.19$ & 15.8 \\
\hline
\end{tabular}

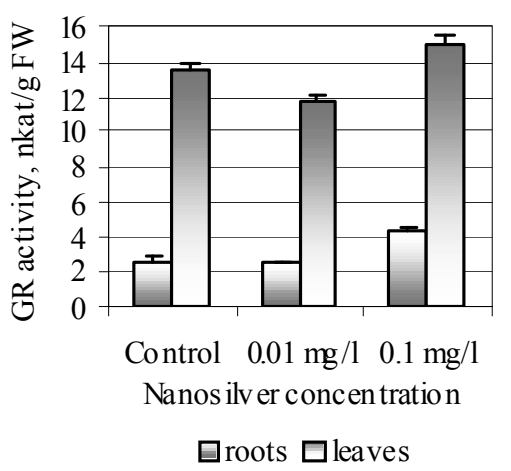

Fig. 2. Effect of AgNPs on GR activity of Hordeum vulgare seedlings

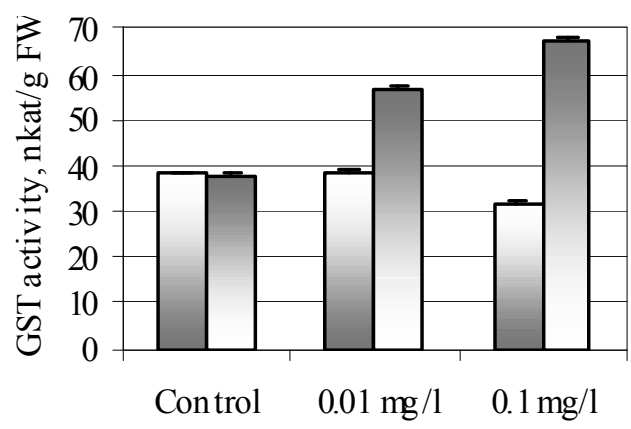

Nano silver con centration

$\square$ roots $\square$ leaves

\section{Fig. 3. Effect of AgNPs on GST activity of Hordeum vulgare seedlings}

It was shown by Mazumdar and Ahmed (2011) that the silver nanoparticles are capable of penetration and deposition inside the root cells of Oryza sativa. In the given research we supposed the possibility of AgNPs deposition in barley seedlings as well, together with glutathione S-transferase activation, insofar as Edwards et al. (2000) established GST's action on different xenobiotics. We have previously shown the glutathione S-transferase activation in roots of pea and maize seedlings exposed to the action of nickel ions at different concentrations (Khromykh et al., 2012), and enzyme activation in Acer platanoides leaves under pollutants action
(Khromykh et al., 2014). However, a significant growth of GST activity as a response to the action of nano-silver was only observed in leaves of barley seedlings (Fig. 3).

According to the results, glutathione S-transferase activation $(50 \%$ and $78 \%$ respectively, at low and high concentrations; $\mathrm{P}<0.05)$ indicated an intensive detoxification process in barley leaves; but elucidation of the nature of the toxicant (silver nanoparticles directly or certain metabolites) requires further investigations.

\section{Conclusion}

The present study investigated the effect of silver nanoparticles on barley (Hordeum vulgare) seedlings after the exposure of seeds to different concentrations of AgNPs. We observed a significant increase in leaf length, fresh weight, and surface area, as well as inhibition of growth of roots. Diminution of peroxidase activity in leaves and enzyme activation in roots were established. Accumulation of GSSG together with decline in the GSH/GSSG ratio in roots indicated damage to the redox balance in barley root cells both at low and high concentrations of nano-silver. The growth of GR activity both in roots and leaves at high concentration and GST activity in leaves at both concentrations suggest the reaction of the defence glutathione system of barley seedlings to the influence of AgNPs. It was found that modifications of seedlings growth parameters as well as antioxidant processes in barley roots and leaves depended on the concentration of silver nanoparticles. The varied directions of changes in growth, metabolic processes and activity of antioxidant defense systems appear to be a stress response of barley seedlings to the action of AgNPs and indicate the importance of detailed study of changes in plants' intracellular processes when exposed to the action of nanomaterials.

\section{References}

An, J., Zhang, M., Wang, S., Tang, J., 2008. Physical, chemical and microbiological changes in stored green asparagus spears as affected by coating of silver nanoparticles. Food Sci. Technol. 41, 1100-1107. 
Anderson, M.E., 1985. Determination of glutathione and glutathione disulfide in biological samples. Method. Enzymol. $113,548-555$.

Ashrafi, M., Sarajuoghi, M., Mohammadi, K., Zarei, S., 2013. Effect of nanosilver application on agronomic traits of soybean in relation to different fertilizers and weed density in field conditions. Env. Exp. Biol. 11, 53-58.

Bradford, M.M., 1976. A rapid and sensitive method for the quantitation of microgram quantities of protein utilizing the principle of protein-dye binding. Anal. Biochem. 72(1-2), 248-254.

Carlberg, I., Mannervik, B., 1985. Glutathione reductase Method. Enzymol. 113, 484-490.

Choi, O., Clevenger, T.T., Deng, B., Sarampalli, R.Y., 2009. Role of sulfide and ligand strength in controlling nanosilver toxicity. Water Res. 43(7), 1879-1886.

Edwards, R., Dixon, D.P., Walbot, V., 2000. Plant glutathione S-transferases: Enzymes with multiple functions in sickness and in health. Trends Plant Sci. 5(5), 193-198.

Elechiguerra, J.L., Burt, J.L., Morones, J.R., Camacho-Bragado, A., Gao, X., Lara, H.H., Uacaman, M.J., 2005. Interaction of silver nanoparticles with HIV-1. J. Nanobiotechnology 3. 6.

Gill, S.S., Tuteja, N., 2010. Reactive oxygen species and antioxidant machinery abiotic stress tolerance in crop plants. Plant Phys. Biochem. 48(12), 909-930.

Habig, W.H., Pabst, M.J., Jakoby, W.B., 1974. Glutathione S-transferase. The first step in mercapturic acid formation. J. Biol. Chem. 249(22), 7130-7139.

Khot, L.R., Sankaran, S., Maja, J.M., Ehsani, R., Schuster, N.E.W., 2012. Applications of nanomaterials in agricultural production and crop protection: A review. Crop Protection $35(5), 64-70$.

Khromykh, N.O., Bilchuk, V.S., Rossykhina-Galycha, G.S., Vinnychenko, O.M., 2014. Sezonna dynamika antyoxidantnykh protsessiv u lystkah Acer negundo za diy polyutantiv [Seasonal dynamics of antioxidative processes in Acer negundo leaves under pollutant action]. Visn. Dnipropetr. Univ. Ser. Biol. Ecol. 22(1), 71-76 (in Ukrainian).

Khromykh, N.O., Boroday, E.S., Lykholat, U.V., 2012. Faktorniy analiz vplivu nikelyu ta gipertermiy na vmist vidnovlenogo glutationu ta aktivnist glutation-S-transferazi u korenyah kukurudzi ta gorohu [Factorial analysis of $\mathrm{Ni}^{2+}$ and heat action on reduced glutathione content and glutathione S-transferase activity in maize and pea roots]. Bulletin of Kharkiv National Agrarian University, Series Biology 3(27), 75-81 (in Ukrainian).
Krishnaraj, C., Jagan, E.G., Ramachandran, R., Abirami, S.M., Mohan, N., Kalaichelvan, P.T., 2012. Effect of biologically synthesized silver nanoparticles on Bacopa monnieri (Linn.) Wettst. plant growth metabolism. Process Biochem. 47(4), 651-658.

Lee, W.-M., Kwak, J.I., An, Y.-J., 2012. Effect of silver nanoparticles in crop plants Phaseolus radiatus and Sorghum bicolor: Media effect on phytotoxicity. Chemosphere 86(5), 491-499.

Lin, D., Xing, B., 2008. Root uptake and phytotoxicity of $\mathrm{ZnO}$ nanoparticles. Environ. Sci. Technol. 42, 5580-5585.

Mazumdar, H., Ahmed, G.U., 2011. Phytotoxicity effect of silver nanoparticles on Oryza sativa. I. J. ChemTech. Res. 3(3), 1494-1500.

Nair, R., Varghese, S.H., Nair, B.G., Maekawa, T., Yoshida, Y., Kumar, D.S., 2010. Nanoparticulate material delivery to plants. Plant Sci. 179(3), 154-163.

Noctor, G., Arisi, A.C.M., Jounanin, L., 1998. Glutatione: Biosinthesis, metabolism and relationship to stress tolerance explored in transformed plants. J. Exp. Bot. 49(321), 623-647.

Noctor, G., Gomez, L., Vanacker, H., Foyer, C.H., 2002. Interaction between biosynthesis, compartmentation and transport in the control of glutathione homeostasis and signaling. J. Exp. Bot. 53(372), 1283-1304.

Ranieri, A., Castagna, A., Baldam, B., Soldatin, G.F., 2001. Iron deficiency differently affects peroxidase isoforms in sunflower. J. Exp. Bot. 52(354), 25-35.

Rezvani, N., Sorooshzadeh, A., Farhadi, N., 2012. Effect of nano-silver on growth of saffron in flooding stress. World Acad. Sci. Eng. Technol. 6(1), 517-522.

Ros Barcelo, A., 1987. Quantification of lupin peroxidase isoenzymes by densitometry. Anales de Biologia 14(3), 33-38.

Salama, H.M.H., 2012. Effects of silver nanoparticles in some crop plants, Common bean (Phaseolus vulgaris L.) and corn (Zea mays L.). Int. Res. J. Biotech. 3(10), 190-197.

Seif, S.M., Sorooshzadeh, A., Rezazadehs, H., Naghdibadi, H.A., 2011. Effect of nanosilver and silver nitrate on seed yield of borage. J. Med. Plant Res. 5(2), 171-175.

Syu, Y.-Y., Hung, J.-H., Chen, J.-C., Chuang, H.-W., 2014. Impacts of size and shape of silver nanoparticles on Arabidopsis plant growth and gene expression. Plant Phys. Biochem. 83(10), 57-64.

Woodward, G.E., Fry, E.G., 1932. The determination of blood glutathione. J. Biol. Chem. 97, 465-482.

Надійшла до редколегії 03.07.2015 